\title{
Mark $\mathcal{T}_{\text {wain's }}$
}

\section{Letters from Hawaii}





\section{Mark Twain's}

Letters from Hawaii

1

Edited and with an Jntroduction

$$
\text { by A. Grove Day }
$$

University of Hawaii Press

Honolulu 


\section{PUBLISHED ORIGINALLY BY APPLETON-CENTURY UNIVERSITY OF HAWAII PRESS EDITION 1975}

$$
\begin{array}{llll}
17 & 18 & 22 & 21
\end{array}
$$

COPYRIGHT @ I966 BY A. GROVE DAY

ALL RIGHTS RESERVED

PRINTED IN THE UNITED STATES OF AMERICA

Library of Congress Cataloging-in-Publication Data

Clemens, Samuel Langhorne, 1835-1910.

Mark Twain's letters from Hawaii.

Reprint of the ed. published by Appleton-Century, New York.

1. Clemens Samuel Langhorne, 1835-1910-Journeys.

2. Hawaii-Description and travel-To 1950.I. Day, Arthur Grove, 1904- ed.II. Title.

PS1331.A3D3 1975 919.69'03'2 74-31359

978-0-8248-0288-2

University of Hawai'i Press books are printed on acid-free paper and meet the guidelines for permanence and durability of the Council on Library Resources.

www.uhpress.hawaii.edu 